\title{
Ergotamine Tartrate
}

National Cancer Institute

\section{Source}

National Cancer Institute. Ergotamine Tartrate. NCI Thesaurus. Code C47517.

The tartrate salt form of ergotamine, an ergot alkaloid and adrenergic alpha agonist with vasoconstrictor activity. Ergotamine tartrate selectively binds to alpha-adrenergic receptors thereby stimulating vascular smooth muscle and causing vasoconstriction in both arteries and veins. Ergotamine tartrate also blocks serotonin 5-HT1D receptors, thereby also causing vasoconstriction in cerebral blood vessels. Constriction of cerebral blood vessels caused by this agent may reduce the blood flow and pressure in cerebral arteries and may relieve the pain of vascular headaches. 